\title{
Developments
}

\section{Mainstreaming Equality in European Structural and Investment Funds: Introducing the Novel Conditionality Approach of the 2014-2020 Financial Framework}

\author{
By Viorica Viță ${ }^{*}$
}

\begin{abstract}
This paper explores a novel equality mainstreaming tool in EU spending-the "ex-ante conditionality"-as introduced in the 2014-2020 European Structural and Investment Funds. It shows that conditionality is a response to the modest achievements of prior equality-mainstreaming action in spending, but that its current legal construct and operation risk propagating similar shortcomings. The article concludes by emphasizing the importance of mainstreaming as a crucial tool for progressive achievement of equality and social justice in the EU, and highlights four essential elements to be addressed for a successful equality mainstreaming policy in EU spending.
\end{abstract}

\footnotetext{
*Viorica Viță is a Ph.D. researcher in law at the European University Institute, Florence (Italy) and a Fulbright Schuman visiting researcher at New York University and Harvard Law School (2016-2017), viorica.vita@eui.eu. The author expresses her gratitude to the participants of the 2015 Workshop for Young EU Lawyers organized by LSE, in particular to Floris de Witte and Jan Komárek for their thoughtful comments on earlier versions of this paper. The views expressed herein, as well as any possible, errors are solely those of the author.
} 
"If a great many remedies are prescribed against an illness, it means the illness is incurable." -Anton Chekhov, The Cherry Orchard ${ }^{1}$

\section{A. Introduction}

Equality mainstreaming in spending was proudly presented by EU policy makers in the mid-1990s as a cure for all syndromes of inequality in all actions implementing EU Structural Funds at all levels. ${ }^{2}$ The policy tool was meant to be a breakthrough towards genuine enjoyment of equality in EU spending action and beyond. Further fueled by the 1999 Amsterdam treaty commitment to mainstream gender in all Union actions, ${ }^{3}$ the tool quickly gained impressive popularity and increased presence in funding regulations. At the same time, mainstreaming extended in substantive scope, reaching beyond its initial focus on gender equality to encompass non-discrimination and the protection of persons with disabilities.

Despite the strong constitutional mandate, institutional support, and the growing number of approaches proposed by the EU to render mainstreaming a powerful policy instrument of spending, the record of the Member States fell short in meeting the initial high expectations. ${ }^{4}$ Although the vocabulary of equality mainstreaming became virtually omnipresent in the programming documents of Structural Funds, the actual implementation of mainstreaming into spending practice proved to be highly challenging. ${ }^{5}$

Nevertheless, the EU did not give up. In the 2014-2020 financial period the EU introduced a new tool: The ex ante conditionality in the areas of gender equality, non-discrimination, and

\footnotetext{
${ }^{1}$ Anton CHeKhov, The CherRy ORCHARd 27 (Richard Nelson, Richard Pevear \& Larissa Volockonsky trans., Theatre Comm. Group 2015).

2 Eur. Comm'n, Communication on Incorporating Equal Opportunities for Women and Men in All Community Policies and Activities, COM (1996) 67 final (Feb. 21, 1996), endorsed by Council Resolution of 2 December 1996 on Mainstreaming Equal Opportunities for Men and Women into the European Structural Funds, 1996 O.J. (C 386) 1 (EU); Eur. Comm'n, Communication on Equality of Opportunity for People with Disabilities, A New European Community Disability Strategy, COM (1996) 406 final (Dec. 20, 1996).

3 Treaty of Amsterdam Amending the Treaty on European Union, the Treaties Establishing the European Communities and Certain Related Acts art. 2, 3(2), Oct. 2, 1997, 1997 O.J. (C 340) 1 [hereinafter Treaty of Amsterdam].

${ }^{4}$ See infra Part B.II.

${ }^{5}$ Id.
} 
disability-jointly the "equality conditionalities." ${ }^{6}$ The three conditionalities are part of a much wider ex ante conditionality package of 2014-2020 spending. ${ }^{7}$ The three conditionalities check that the right administrative and institutional preconditions are in place to ensure sound equality mainstreaming throughout EU funded actions, prior to disbursement of funding. ${ }^{8}$ Should the Member States fall short in proving sufficient mainstreaming capacity, funding may be suspended. ${ }^{9}$

From this point of view, conditionality may be seen as a new managerial tool used to strengthen a binding, yet non-enforceable EU legal obligation-the duty to mainstream equality. Interestingly, this law and policy enforcement function of conditionality links to broader scholarly discussions on finding the appropriate tools to support the enforcement of EU values articulated under Article 2 of the TEU. ${ }^{10}$ Like the foundational values of the EU, the obligation to mainstream is a "gracious" treaty obligation, graciously transposed into the text of funding regulations. Hence, confronted again with the question of how to go about a treaty obligation that lacks a dedicated enforcement mechanism, the Commission opted for a novel ex ante conditionality.

Aiming to explore these novel conditionality arrangements, the present contribution begins with an analysis of the equality-mainstreaming mandate of the EU and its record in the area of European Structural and Investment Funds. Subsequently, this Article introduces the three equality conditionalities, contrasting them against the preexisting mainstreaming obligations, inquiring about their potential added value. The contribution concludes that the prior mainstreaming "cures" have had a limited effect on improved functioning of the tool, and that the current conditionality approach risks propagating the same pathologies. However, the Article does not conclude that the identified mainstreaming challenges are

${ }^{6}$ Regulation (EU) No. 1303/2013, art. 2(33), 19, annex XI, points 1-3, 2013 O.J. (L 347) 320. See also EUR. COMm'N, INTERNAL GUIDANCE ON EX ANTE CONDITIONALITIES FOR THE EUROPEAN STRUCTURALAND INVESTMENT FUNDS PART I (2014), http:// http://ec.europa.eu/regional_policy/sources/docgener/informat/2014/eac_guidance_esif_part1_en.pdf; EUR. COMm'n, GUIDANCE ON EX ANTE CONDITIONALITIES FOR the EUROPEAN STRUCTURAL AND INVESTMENT FUNDS PART II (2014), http:// http://ec.europa.eu/regional_policy/sources/docgener/informat/2014/eac_guidance_esif_part2_en.pdf.

${ }^{7}$ Regulation(EU) No. 1303/2013, supra note 6, annex XI. Annex XI counts thirty-four ex ante conditionalities, of which seven are general and twenty-seven are thematic. While the general conditionalities may apply to all funds, the thematic conditionalities only apply to the specific investment priorities they are attached to.

8 Id. art. $19(5)$.

${ }^{9} / d$.

10 See Armin Von Bogdandy et al., Reverse Solange: Protecting the Essence of Fundamental Rights Against EU Member States, 49 CMLR 489 (2012); Armin Von Bogdandy \& Michael loannidis, Systemic Deficiency in the Rule of Law: What It Is, What Has Been Done, What Can Be Done, 51 CMLR 59 (2014); Carlos Closa, Dimitry Kochenov \& J.H.H., REINFORCING RULE OF LAW OVERSIGHT IN THE EUROPEAN UNION (2014), http://cadmus.eui.eu/bitstream/handle/1814/30117/RSCAS_2014_25_FINAL.pdf; Dimitry Kochenov, How to Turn Article 2 TEU into a Down-to-Earth Provision?, VerfBLog (Dec. 8, 2013), http://verfassungsblog.de/how-to-turnarticle-2-teu-into-a-down-to-earth-provision/. 
incurable. On the contrary, it argues that in the specific context of EU funding, equality mainstreaming may not in any case be deemed incurable. This is especially true because mainstreaming remains a crucial instrument for equality promotion and observance in the blurry multi-level, shared management construct of EU structural funding.

\section{B. Structural Funds and the EU Mainstreaming Mandate}

Pierre Pescatore stated: "[B]efore one can talk of the substance of legal norms, one must see what the structure is into which these norms are integrated." ${ }^{11}$ Hence, before assessing the impact effect of mainstreaming in Structural Funds and the added value of the novel conditionality arrangements, the present Section intends to briefly present the current construct of Structural Funds and the mainstreaming mandate of the EU treaties. Only after presenting these two crucial constructs may one meaningfully engage in analyzing the success of mainstreaming in EU spending and the potential of various approaches to support this policy goal.

\section{Structural Funds Operation and Equality Mainstreaming as a Primary EU Law Obligation}

European Structural and Investment Funds are the main EU spending instruments supporting the implementation of EU policies in the areas of economic, territorial, and social cohesion, and agriculture and fisheries. The funds have known various configurations and names throughout the years, but for consistency this Article shall generically refer to them as "Structural Funds."

In the current financial period, Structural Funds comprise five funds clustered around three policy areas: Cohesion policy, the Common Agricultural Policy (CAP), and the Common Fisheries Policy. ${ }^{12}$ Cohesion policy funds are represented by the European Regional Development Fund (ERDF), the European Social Fund (ESF), and the European Cohesion Fund. CAP structural funding is delivered under its second pillar, the European Agricultural Fund for Rural Development (EAFRD). Finally, the Fisheries policy is supported through the European Maritime and Fisheries Fund (EMFF). Together, these funds represent the largest bulk of EU budgetary resources, currently amounting to more than forty percent of the total EU budget. ${ }^{13}$

\footnotetext{
${ }^{11}$ Étienne Deschamps, Interview with Pierre Pescatore: Composition and Working Methods of the Legal Group (Luxemburg, Sept. 10, 2003), CVCE (Sept. 10, 2003), http://www.cvce.eu/en/obj/interview_with_pierre_pescatore_composition_and_working_methods_of_the_legal _group_luxembourg_10_september_2003-en-888d433d-2571-452c-a19e-4e64102d36c2.html.

${ }^{12}$ Regulation (EU) No. 1303/2013, supra note 6.

${ }^{13}$ Within the total EU Budget, the ERDF, ESF, and Cohesion Fund jointly amount to $34 \%$, while the EAFRD and EMFF amount to $8 \%$ and $1 \%$, respectively. See Council Regulation (EU, Euratom) No. 1311/2013 of Dec. 2, 2013 Laying
} 
The budgetary execution of the above-mentioned funds is carried out through shared management between the European Commission (the Commission) and Member States under Article 317 of the TFEU and the general principle of subsidiarity. ${ }^{14}$ In practical terms, the multiannual disbursement of Structural Funds is shaped around two main stages: Programming and implementation. This process implies continuous interaction between the Commission and Member States, with particularly strong empowerment of the Commission during the programming stage and greater discretion given to Member States in the implementation stage. During the programming stage, Member States draft their national strategic documents on spending-the programming documents-under the close supervision of the Commission, according to funding regulations. ${ }^{15}$ In the 2014-2020 programming period, a single national programming document is first drafted for all Structural Funds, the Partnership Agreement, ${ }^{16}$ which is subsequently detailed in various thematic programs, the Operational Programs. ${ }^{17}$ The Commission then approves the programming documents by implementing act decisions. During the implementation stage, Member States, through their delegated authorities, are actually implementing EU resources, selecting beneficiaries, and disbursing EU funding. Nevertheless, the Commission remains the main actor responsible for EU budgetary execution, ${ }^{18}$ monitoring the performance of Member States through periodic reports and evaluations, and applying sanctions in cases of spending mismanagement.

Regarding the concept of equality mainstreaming, reference shall be made to the definition put forward by the Commission in the area of gender equality mainstreaming, whereby:

[M]ainstreaming involves not restricting efforts to promote equality to the implementation of specific measures... but mobilising all general policies and measures specifically for the purpose of achieving equality.... This means systematically examining

Down the Multiannual Financial Framework for the Years 2014-2020, 2013 O.J. (L 347) 890. See also EUR. CoMm'N, Multiannual Financial Framework 2014-2020 AND EU Budget 20148 (2013).

${ }^{14}$ See Regulation (EU, Euratom) No. 966/2012 of the European Parliament and of the Council of Oct. 25, 2012 on the Financial Rules Applicable to the General Budget of the Union and Repealing Council Regulation (EU, Euratom) No. 1605/2002, art. 59, 175-80, 2012 O.J. (L 298) 1.

${ }^{15}$ Regulation (EU) No. 1303/2013, supra note 6.

${ }^{16}$ Regulation (EU) No. 1303/2013, supra note 6, art. 14-15.

17 Regulation (EU) No. 1303/2013, supra note 6, art. 2(6), 96.

${ }^{18}$ Consolidated Version of the Treaty on the Functioning of the European Union art. 317, May 9, 2008, 2008 O.J. (C 115) 47 [hereinafter TFEU]. 
measures and policies and taking into account such possible effects when defining and implementing them. ${ }^{19}$

In other words, equality mainstreaming implies bringing equality to the mainstream of all policy formulation and implementation to promote equal opportunities and combat discrimination. The approach intends to expand towards the broader governance spectrum and complement traditional equality-specific actions. It aims to dismantle structural inequalities by rethinking, planning, and implementing all general policies, measures, and institutional cultures from an equality perspective.

At the EU level, equality mainstreaming has its primary legal basis under the EU treaties since the 1997 Amsterdam Treaty. ${ }^{20}$ Under the current Treaty of Lisbon, mainstreaming is upheld as a task of the EU and its institutions, which are mandated to: "[C]ombat social exclusion and discrimination, and ... promote social justice and protection, equality between women and men . .." ${ }^{21}$ Additionally, the Union must aim to "eliminate inequalities and promote the equality between men and women" in all its activities ${ }^{22}$ as well as to combat any discrimination "[i]n defining and implementing its policies and activities." 23

Although the Union and its institutions are the primary addressees of equality mainstreaming, Member States are not exonerated from this obligation. In line with the general principle of sincere cooperation of Article 4(3) of the TEU, Member States must support and assist the EU in mainstreaming efforts and loyally aid it in carrying out this constitutionally mandated task. Similarly, the Charter of Fundamental Rights of the European Union ${ }^{24}$ underlines the role of Member States in promoting equality. In this sense, Article 51(1) of the Charter charges both the Union as well as its Member States to "observe

\footnotetext{
${ }^{19}$ COM (1996) 67 final (1996), supra note 2, point 2.

${ }^{20}$ Treaty of Amsterdam art. 2, 3(2).

${ }^{21}$ Treaty of Lisbon Amending the Treaty on European Union and the Treaty Establishing the European Community, Dec. 13, 2007, 2007 O.J. (C 306) 1 [hereinafter Treaty of Lisbon]; Consolidated Version of the Treaty on European Union art. 3(3), Oct. 26, 2012, 2012 O.J. (C 326) 13.

${ }^{22}$ Treaty of Lisbon; TFEU art. 8.

${ }^{23} /$ d. art. 10.

${ }^{24}$ Charter of Fundamental Rights of the European Union, Oct. 26, 2012, O.J. 2012 (C 326) 391 [hereinafter the Charter].
} 
the principles and promote [the] application thereof," 25 including the general principles of equal treatment, non-discrimination, and integration of persons with disabilities. ${ }^{26}$

The equality mainstreaming policy is not meant to add or otherwise alter the competences of the EU or Member States, as defined under the Treaties. Rather, it aims to ensure that the exercise of preexisting EU competences is planned and implemented consistently with the EU equality agenda. ${ }^{27}$ In other words, mainstreaming is an EU obligation that guides the exercise of existing EU competences. Thus, mainstreaming is not about what, but about how the EU exercises its competence and how the Member States are to implement them.

It is important to stress that in Test-Achats, the Court of Justice (the Court) further supported the special meaning of mainstreaming. ${ }^{28}$ The Court held that when mainstreaming action is taken, the EU legislator must ensure that the adopted measures contribute effectively to the achievement of the goal. ${ }^{29}$ Therefore, when the Union decides to take mainstreaming action, mere mention of equality is not enough. The EU institutions must ensure that mainstreaming measures are actually effective.

\section{The Evolution of Equality Mainstreaming in Structural Funds}

The equality-mainstreaming mandate of Structural Funds follows closely the shared management model of spending execution. Initially, EU legislators transpose the treaty mainstreaming obligations under the Structural Funds regulations. Subsequently, mainstreaming is translated into the programming documents by the Member States. During the programming stage, the Commission assesses the planned mainstreaming action of Member States and, if found satisfactory, approves the programming documents. After Commission approval, actual implementation of mainstreaming action is undertaken largely at the national level under the primary responsibility of Member States. Under the supervision of the Commission, Member States and their designated bodies must ensure that the equality mainstreaming actions agreed upon in the programming documents are effectively translated into practice. Yet, funding regulations do not provide for specific sanctions in cases of failure to mainstream equality at the national level. In this light, mainstreaming is a binding but non-enforceable obligation for Member States.

\footnotetext{
${ }^{25} / d$. art. 51(1) (emphasis added).

${ }^{26}$ Id. art. 20-21, 26.

27 See Olivier De Schutter, Champ d'application, in CommentARY OF THE CHARTER OF FUnDamental Rights 389, 395 (EU Network of Independent Experts on Fundamental Rights 2006).

${ }^{28}$ Case C-236/09, Ass'n Belge des Consommateurs Test-Achats v. Conseil des ministres, 2011 E.C.R I-00773, paras. 20-21 [hereinafter Test-Achats].

${ }^{29} / d$.
} 
The evolutionary analysis of equality promotion through Structural Funds shows that from its very early stages EU spending has been constantly concerned with social justice and status equality. ${ }^{30}$ By the 1988-1993 programming period, specific programs taking shape at the EU and national levels supported the integration of women, youth, groups at risk of discrimination, and persons with disabilities. ${ }^{31}$ Yet, these actions are different from mainstreaming because they materialize as equality positive action supported by spendingthe so-called equality direct action.

Inspired by the Commission's general call to mainstream equality in all EU actions ${ }^{32}-$ including those related to structural funding ${ }^{33}$-from 1996 onward mainstreaming began to complement direct action. This moment marks the birth of equality mainstreaming in Structural Funds. Based on the Commission's commitment to mainstreaming, the 20002006 funding regulations were endowed with a strong mainstreaming approach, particularly in the area of gender equality. ${ }^{34}$ Subsequently, in the 2007-2013 financial period, gender equality is complemented by mainstreaming action in the areas of non-discrimination and inclusion of persons with disabilities. ${ }^{35}$

\footnotetext{
${ }^{30}$ The 1988 funding regulations refer to the integration of young people and groups at risk of social exclusion. See Council Regulation (EEC) No. 2052/88 of June 24, 1988 on the Tasks of the Structural Funds and Their Effectiveness and on Coordination of Their Activities Between Themselves and with the Operations of the European Investment Bank and the Other Existing Financial Instruments, art. 1, 3, 1988 O.J. (L 185) 9. Furthermore, by 1989, the Commission guidance encouraged Member States to budget ESI Funds' resources in the social inclusion of women, people with disabilities, and youth. See also Eur. Comm'n, Guidelines Concerning European Social Fund Intervention in Respect of Action Against Long-Term Unemployment and Occupational Integration of Young People (Objectives 3 and 4 in the Context of the Reform of the Structural Funds), 1989 O.J. (C 45) 6.

${ }^{31}$ See, e.g., Eur. Comm'n, Notice to the Member States Laying Down Guidelines for Operational Programmes/Global Grants, which Member States Are Invited to Establish, Within the Framework of a Community initiative to Promote Equal Opportunities for Women in the Field of Employment and Vocational Training - NOW INITIATIVE, 1990 O.J. (C 327) 5. Eur. Comm'n, The Future of Community Initiatives under the Structural Funds, at 32, COM (1993) $282 \mathrm{final}$ (June 19, 1993).

${ }^{32}$ COM (1996) 67 final (Feb. 21, 1996), supra note 2, at 2. The mainstreaming model was initially focused on gender equality and inspired by the gender equality strategy as agreed on at the 1995 United Nations World Conference on Women. See Fourth World Conference on Women, Report of the Fourth World Conference on Women, U.N. DOC. A/CONF.177/20 (Sept. 4, 1995).

${ }^{33}$ COM (1996) 67 final (Feb. 21, 1996), supra note 2, at 15-19.

${ }^{34}$ Council Regulation (EC) No. 1260/1999, 1999 O.J. (L 161) 1.

${ }^{35}$ Council Regulation (EC) No. 1083/2006, art. 16, 2006 O.J. (L 210) 25.
}

\begin{abstract}
The Member States and the Commission shall ensure that equality between men and women and the integration of the gender perspective is promoted during the various stages of implementation of the Funds.
\end{abstract}

The Member States and the Commission shall take appropriate steps to prevent any discrimination based on sex, racial or ethnic origin, 
In practical terms, the funding regulations called upon Member States to ensure that gender equality, non-discrimination, and inclusion of persons with disabilities would be mainstreamed as general principles into all spending action. ${ }^{36}$ Furthermore, mainstreaming obligations referred inter alia to statistics broken down by sex, ${ }^{37}$ the promotion of an equality perspective into ex ante evaluations, ${ }^{38}$ the establishment of partnership arrangements with equality bodies and civil society, ${ }^{39}$ and a gender-balanced composition of managing bodies. ${ }^{40}$

These broad mainstreaming requirements were translated into practice with difficulty. Two decades of equality mainstreaming in Structural Funds show that the glass is half empty, rather than half full. On the half-full side, the policy proved highly successful in developing a virtually omnipresent vocabulary of equality, ${ }^{41}$ as well as raising awareness on equality policy at the national level. ${ }^{42}$ On the half-empty side, however, the commitment to mainstreaming largely remained declaratory and inconsistent, ${ }^{43}$ lacking a systematic approach. ${ }^{44}$ Evaluations show that although the vast majority of programming documents acknowledged the importance of equal opportunities and non-discrimination principles, ${ }^{45}$

\footnotetext{
religion or belief, disability, age or sexual orientation during the various stages of implementation of the Funds and, in particular, in the access to them. In particular, accessibility for disabled persons shall be one of the criteria to be observed in defining operations co-financed by the Funds and to be taken into account during the various stages of implementation.

${ }^{36} / d$.

${ }^{37}$ Id. at art. 66.

${ }^{38}$ Council Regulation (EC) No. 1260/1999, supra note 34, at art. 41.

${ }^{39}$ Id. at art. 10 .

${ }^{40}$ Council Regulation (EC) No. 1083/2006, supra note 35, at art. 1, 2, 3, 8, 12, 20, 29, 41, 46.

${ }^{41}$ Fondazione G. Brodolini, Evaluation of the European Social Fund's Support to Gender Equality 138-39 (2011). See also EUR. COMM'N, FOURTH REPORT ON ECONOMIC AND SOCIAL COHESION 113 (2007), http://ec.europa.eu/regional_policy/sources/docoffic/official/reports/cohesion4/pdf/4cr_en.pdf.

42 Pub. Policy and Mgmt. Inst., Study on the Translation of Article 16 of the Regulation (EC) N 1083/2006 ON the Promotion of Gender Equality, NON-Discrimination ANd ACCESSIBILITY FOR DisAbled PeRSONS INTO COHESION PROGRAMMES 2007-2013 (2009).

43 John Bachtler \& Sandra Taylor, Eur. Policies Research Ctr. Univ. Of Strathclyde, Objective 2: ExPeRiences, Lessons AND POLICY IMPLICATIONS 195 (1999).

${ }^{44}$ Id. See also Council Regulation (EC) No. 1260/1999, supra note 34.

45 Id. BACHTLER \& TAYLOR at 3.
} 
only eight percent have taken due account of the principles in the spending actions of 20072013. ${ }^{46}$ Moreover, when present, equality mainstreaming actions were usually limited to the European Social Fund, ${ }^{47}$ and only rarely considered in areas attracting higher financial support, such as the European Regional Development Fund (ERDF). ${ }^{48}$ The evaluation of the ERDF even went so far as to raise doubt about the feasibility and suitability of gender mainstreaming as a horizontal principle of regional development spending. ${ }^{49}$

Furthermore, under the pressure of equality mainstreaming, the budgetary resources dedicated to equality direct actions have substantially decreased since $2000 .{ }^{50}$ The cut was justified by the expected success of mainstreaming, which was in turn expected to lower the costs of promoting equality. Nevertheless, while funding commitments were actually reduced, mainstreaming had little to offer in exchange.

In response to the shortcomings of mainstreaming at the national level, the Commission exercised what Barca called "moral suasion." 51 After the approval of programming documents, the Commission lacked a specific enforcement instrument to ensure thorough adherence to mainstreaming efforts. The use of the infringement procedure for failures of mainstreaming equality in funding operations was seen as being too intrusive and, consequently, it has never been considered in practice. Therefore, the Commission

${ }^{46} / d$.

${ }^{47}$ Eur. Court of Auditors, Special Report No. 22/98, 1998 O.J. (C 393) 24.

48 Mary Braithwaite, Mainstreaming Gender in European Public Policy Workshop at the University of Wisconsin-Madison: Mainstreaming Gender in the European Structural Funds (Oct. 14-15, 2000).

${ }^{49}$ Eur. Comm'n, Ex-Post Evaluation of Cohesion Policy Programmes 2000-06 Co-Financed by the erdf (Objectives 1 \& 2) $110 \quad$ (2010), http://ec.europa.eu/regional_policy/sources/docgener/evaluation/pdf/synthesis_eval2000_2006.pdf ("[S]imply including an issue [gender mainstreaming] a horizontal priority, therefore, does not ensure that it actually has a significant effect on policy unless it is perceived as being important, in which case action would probably be taken irrespective of whether it is a horizontal priority or not.").

${ }^{50}$ Fondazione Giacomo Brodolini, Eur. Parl.Information note PE 462.426, 'The multi-annual financial framework 2014-2020 from a gender equality perspective' (2012) 43,

http://www.europarl.europa.eu/document/activities/cont/201201/20120123ATT36024/20120123ATT36024EN.p df. ("[T]he programmed resources specifically dedicated to gender-equality actions have decreased by $34 \%$. .).

${ }^{51}$ Fabrizio Barca, An Agenda for a Reformed Cohesion Policy: A Place-Based Approach to Meeting European Challenges AND EXPECTATIONS 50 (2009). 
continued to promote mainstreaming through soft-law guiding instruments, which include communications ${ }^{52}$ and working papers. ${ }^{53}$

\section{The Equality Conditionalities of the 2014-2020 Financial Period}

The 2014-2020 funding regulations closely maintain the mainstreaming obligations identified in the last programming periods. These regulations are notably distinguishable by their inclusion of three equality conditionalities in the areas of gender equality, non-discrimination, and inclusion of persons with disabilities. ${ }^{54}$

The equality conditionalities are general and ex ante. They apply in principle to all five Structural Funds and must be in place before the actual disbursement of EU financial resources. As to their scope, the conditionalities introduce a set of administrative capacity obligations to be put in place by Member States. The obligations include: Equality training of national officials, institutional arrangements with equality bodies, and monitoring. The intended result of the conditionalities is the strengthening of the administrative capacity of national authorities, which ultimately would positively affect the delivery of equality mainstreaming. Yet, how fit are the new tools for attaining this goal? This is the most pressing question, and one which this Article shall further examine.

\section{Equality Conditionalities: Criteria and Applicability Test}

From a substantive point of view, the three equality conditionalities require Member States to ensure sound administrative capacity to effectively implement and apply the EU

\footnotetext{
52 Eur. Comm'n, Implementation of Gender Mainstreaming in the Structural Funds Programming Documents 20002006 COM (2002) 748 final (Dec. 20, 2002); Eur. Comm'n, Communication Concerning the Structural Funds and Their Coordination with the Cohesion Fund Guidelines for Programmes in the Period 2000 to 2006, 1999 O.J. (C 267) 2; Eur. Comm'n, The Structural Funds and Their Coordination with the Cohesion Fund-Revised Indicative Guidelines, COM (2003) 499 final (Jul. 18, 2003).

${ }^{53}$ See, e.g., Eur. Comm'n, Technical Paper 3: Mainstreaming Equal Opportunities for Women and Men In Structural Fund Programmes And Projects, (2000), http://ec.europa.eu/regional_policy/sources/docoffic/working/doc/mainst_en.pdf.

${ }^{54}$ Regulation (EU) No. 1303/2013, supra note 6, annex XI, pt. II, points 1-3. The equality conditionalities had a hard journey during the negotiations on the 2014-2020 Funding Regulations. These conditionalities have been the object of sharp disputes in regards to their appropriateness and necessity in the context of ESI Funds. As such, the equality conditionalities were initially completely set aside during the Danish presidency negotiations. Later, they were reinserted under the Lithuanian presidency compromise after being substantially changed as compared to the initial Commission's proposal. See EU Council, Cohesion Policy Legislative Package. Presidency compromise on ex ante conditionalities, no $12543 / 2 / 11 \quad$ REV 2 Annex IV 12012 (2012) 20 http://register.consilium.europa.eu/doc/srv?l=EN\&f=ST\%208207\%202012\%20ADD\%202\%20REV\%202; Eur. Comm'n, Proposal, annex IV, COM (2011) 615 final/2 (Mar. 14, 2012).
} 
non-discrimination and gender equality rules, as well as the UN Convention on the Rights of Persons with Disabilities (UNCRPD) throughout all the operations of Structural Funds. ${ }^{55}$

Administrative capacity is assessed against two main criteria. ${ }^{56}$ First, Member States must train staff involved in the management and control of funding in the three equality areas. ${ }^{57}$ Second, Member States must show that they have put in place arrangements that involve equality bodies during the design and implementation of funds. ${ }^{58}$ Additionally, in the specific area of protection of persons with disabilities, Member States must show appropriate arrangements to monitor the accessibility of persons with disabilities in EU spending action. $^{59}$

As mentioned above, the equality conditionalities are general. In principle, they may apply to all Structural Funds. In practice, however, the reach of conditionalities is substantially counter-balanced by cumbersome applicability rules. Any equality conditionality shall apply to a given spending action only if it proves: "A concrete and precisely pre-defined critical factor, which is a prerequisite for and has a direct and genuine link to, and direct impact on, the effective and efficient achievement of a specific objective for an investment priority or a Union priority." 60

In other words, the applicability of each conditionality shall be assessed on a case-by-case basis against each investment priority of a given Member State. Moreover, the conditionality shall be deemed applicable only if it proves critical to effectively achieving the objective of spending. Should that not be the case, the conditionality shall not be applicable.

To illustrate the operation of conditionality applicability rules, consider the example of gender equality conditionality in the European Maritime and Fisheries Fund (EMFF). If one presumes that a Member State plans to invest its EMFF allocation in professional training ${ }^{61}$ one recognizes that sound administrative capacity on gender equality is not essential to ensure that training is effective, in the sense that the intended result is reached. Indeed, training on fisheries may be performed well without a gender equality perspective involved. Nevertheless, if one takes into account the efficiency of spending, the gender equality

\footnotetext{
${ }^{55}$ /d., Regulation (EU) No. 1303/2013.

${ }^{56} / d$.

${ }^{57} / d$.

${ }^{58} / d$.

${ }^{59} / d$. at point 3.

$60 / d$. at art. 2(33).

${ }^{61}$ Regulation (EU) No. 508/2014, art. 6(1)(f), 6(2)(e), 2014 O.J. (L 149) 1.
} 
conditionality is necessarily applicable. Contrary to effectiveness which is simply concerned with the achievement of a given result, training-efficiency refers to the attainment of the best possible ratio between the resources employed and the achieved result. ${ }^{62} \mathrm{~A}$ professional training scheme implemented in the absence of sound administrative capacity on gender equality is less likely to deliver the EU's inclusive growth goal of effectively addressing occupational segregation and supporting the inclusion of women into male dominated sectors. Therefore, gender equality conditionality should be considered essential for an effective and efficient attainment of a desired spending result, and thus consequently applicable. In this sense, prior gender equality training of the managing bodies could help integrate gender concerns at each stage of the planned project, while the involvement of an equality body could provide expert advice on the most effective way to do so. The same approach shall be followed with actions budgeted under the European Agricultural Fund for Rural Development (EAFRD), the European Cohesion Fund, the European Regional Development Fund (ERDF), and the European Social Fund (ESF).

The assessment of applicability and implementation of the equality conditionalities largely takes place in the programming stage, and, as such, is ex ante. To this end, Member States identify the applicable equality conditionalities and report on their fulfillment to the Commission. ${ }^{63}$ The Commission subsequently checks the self-assessment of Member States and approves or proposes changes to the list of conditionalities where it disagrees with the initial applicability or fulfillment analysis. ${ }^{64}$ If the conditionalities are not fulfilled, Member States may be granted an additional compliance period after the approval of the programming documents, but the additional compliance period may not go beyond December 31, 2016. ${ }^{65}$ In these circumstances, Member States are required to put in place detailed action plans indicating the list of conditionalities not fulfilled, the time frame for fulfillment, and the responsible national authorities. ${ }^{66}$ When the Commission decides that an unfulfilled conditionality might cause a "significant prejudice" to the committed funds, it may suspend the financial resources already adopted by the program. ${ }^{67}$ If no significant prejudice is found, funding will be disbursed even if the conditionalities are not fulfilled. But,

\footnotetext{
${ }^{62}$ Regulation (EU, Euratom) No. 966/2012, art. 3(2), 2012 O.J. (L 298) 1.

${ }^{63}$ Regulation (EU) No. 1303/2013, supra note 6, at art. 19.

${ }^{64} / d$.

${ }^{65}$ Id. at art. 19(2).

${ }^{66} / d$.

${ }^{67} / d$. at art. 19(5).
} 
when detailed action plans were not in place by the end of 2016 , suspension may be reconsidered. ${ }^{68}$

Returning to the example of professional training under EMFF, if the gender equality conditionality is not fulfilled, one would expect the Commission to grant an additional compliance period that does not exceed the end of 2016. But, when directed at professional training and the inclusion of women in the fisheries sector, the conditionality should be deemed indispensable and funding should be suspended immediately. Once the Commission has approved the programming documents of the Member States, and the list of conditionalities therein, no changes to the list of applicable conditionalities or fulfilled conditionalities may be made. ${ }^{69}$

Furthermore, the overall procedure on the applicability and enforcement of conditionalities must take into account the principle of proportionality. ${ }^{70}$ The applicability of all equality conditionalities shall take note of, inter alia, "the level of allocated support" and the "overall aim of reducing the administrative burden on the management and control bodies."71 Therefore, when the allocated resources are too small compared to the implied administrative burden, the conditionality might be found non-applicable. A similar result might be reached when the burden of implementing conditionality outweighs the expected benefits. The principle of proportionality shall also be observed in the case of suspension when the "significant prejudice" caused by an unfulfilled conditionality shall be established with regard to the level of risk for the Structural Funds, as well as the degree of nonfulfillment of the conditionality. ${ }^{72}$ Yet, in both instances, nothing explicitly indicates how to assess or apply the principle of proportionality. ${ }^{73}$

\section{From Conditionality in Books to Conditionality in Action}

The complex and elaborate ex ante conditionality applicability rules explained above have little relevance to actual practice. A first glance at the 2014-20 programming documents as approved by the Commission shows that the commitment of each Member State and each Directorate-General (DG) in charge of funding co-management is critical to the implementation of equality conditionalities.

\footnotetext{
${ }^{68}$ Regulation (EU) No. 1303/2013, supra note 6, at art. 19. See also INTERNAL GUIDANCE ON EX ANTE CONDITIONALITIES FOR THE EUROPEAN STRUCTURAL AND INVESTMENT FUNDS PART I, supra note 6.

${ }^{69}$ Regulation (EU) No. 1303/2013, supra note 6, at art. 19.

$70 / d$. at art. 4(5).

${ }^{71} / d$. at art. 4(5), 19(3) (emphasis added).

${ }^{72} / d$. at art. 19(5).

${ }^{73}$ Eur. Court of Auditors, Opinion No. 7/2011, 2012 O.J. (C 47) 1, 9.
} 
This Section begins with an examination of fisheries funding programs and concludes that none of the aforementioned hypothetical examples shall actually see daylight in the present programming period because none of the Member States found the equality conditionalities applicable in their EMFF programming documents. ${ }^{74}$ This circumstance resulted from the Guidance document on ex ante conditionalities prepared by DG Maritime Affairs and Fisheries (DG MARE), whereby the Commission explicitly directed Member States to concentrate on another set of ex ante conditionalities. ${ }^{75} \mathrm{As}$ a result, all EMFF programming documents exclusively observe the advised conditionalities and unanimously exclude from their scope the conditionalities of non-discrimination, gender equality, and disability. ${ }^{76}$ Although the current finding is striking, one could argue that the outcome is in line with the principle of proportionality. ${ }^{77}$ More specifically, in this case, one could refer to the modest financial allocation of the EMFF-below one percent of the total EU budget-and the administrative burden that would result from institutional and training arrangements required by the equality conditionalities. And yet, the outcome here is nonetheless upsetting. This is especially true considering the ex ante conditionality applicability rules which were not applied. Moreover, the outcome is hard to accept if one considers the general mainstreaming mandate that is applicable to all Structural Funds, as well as the explicit obligations to promote equality in the EMFF. ${ }^{78}$

At the opposite end of the practice spectrum sit rural development funding managed under the supervision of DG Agriculture and Rural Development (DG AGRI), and social funding supervised by DG Employment, Social Affairs, and Inclusion (DG EMPL). In both cases, equality conditionalities appear in virtually every national programming document. ${ }^{79}$

\footnotetext{
${ }^{74}$ Findings based on an analysis of EMFF operational programs. See Eur. Comm'n, EMFF - Country Files: Operational Programmes 2014-2020, EUR. COMM'N, http://ec.europa.eu/fisheries/cfp/emff/country-files/index_en.htm (last updated June 4, 2017).

75 Public procurement, state aid, EU environmental law, and statistical systems. See EUR. COMm'N, DRAFT GUIDANCE: EMFF SPECIFIC EX-ANTE CONDITIONALITIES VERSION 3 (MAR. 7, 2014) (2014), http://ec.europa.eu/fisheries/reform/emff/doc/10-guidance-emff-specific-eacs_en.pdf.

${ }^{76}$ Eur. Comm'n, EMFF - Country Files: Operational Programmes 2014-2020, supra note 74.

77 Regulation (EU) No. 1303/2013, supra note 6, art. 4(5), 19 (3).

${ }^{78}$ Regulation (EU) No. 508/2014, supra note 61, at 2 ("The Union should, at all stages of implementation of the EMFF, aim to eliminate inequalities and promote equality between men and women, as well as to combat discrimination based on sex, racial or ethnic origin, religion or belief, disability, age or sexual orientation.") (emphasis added). Moreover, under Article 113 the monitoring Committee should: "[E]xamine actions to promote equality between men and women, equal opportunities, and non-discrimination, including accessibility for disabled persons." Id. at 55 (emphasis added).

79 Findings based on an analysis of EAFRD national programs and ESF national programs. See Eur. Comm'n, Rural Development 2014-2020: Country Files, EUR. COMM'N, https://ec.europa.eu/agriculture/rural-development-2014-
} 
Professional training programs budgeted within the areas of rural development or employment from EAFRD or ESF resources would have to comply with the three equality conditionalities and their fulfillment criteria.

In between these two sides, one finds funding for economic and territorial cohesion implemented under the supervision of DG Regional and Urban Policy (DG REGIO). In this case, the practice of conditionality fluctuates highly. On the one hand, all Partnership Agreements-the single programming documents of the Member States-found the equality conditionalities applicable. ${ }^{80}$ On the other hand, an analysis of the Operational Programs financed from ERDF and the Cohesion Fund shows that the approach to equality conditionalities is state-specific and fluctuant, making it very difficult to discern the objective reasons for their presence or absence throughout the Operational Programs. ${ }^{81}$ More specifically, about half of the Member States have found the equality conditionalities universally applicable under all budgeted national action in the area, irrespective of the thematic scope of the Operational Programs. ${ }^{82}$ At the same time, certain Member States excluded their application from infrastructure, transport, environment, ${ }^{83}$ or economic competitiveness programs. ${ }^{84}$ Some Member States do not make any specific reference to equality conditionalities under their Operational Programs. ${ }^{85}$ Interestingly, in four Member States, the required institutional and training criteria for gender equality, non-discrimination, and disability were not fulfilled upon the approval of the Operational

2020/country-files_en (last updated June 4, 2017); Eur. Comm'n, European Social Fund - Operational Programmes, EUR. COMM'N, http://ec.europa.eu/esf/main.jsp?catld=576\&langld=en (last updated Dec. 12, 2015).

${ }^{80}$ This conclusion is based on the analysis of the published programming documents of the 28 Member States.

${ }^{81}$ For instance, the Operational Programs on Environment, Transport, and Regional Development for Bulgaria do not mention any of the three equality conditionalities despite the programs implying social inclusion action. Comparatively, all the Operational Programs for the Czech Republic adopted in the same areas mention the three conditionalities. See Eur. Comm'n, Programmes-Regional Policy, EUR. Comm'N, http://ec.europa.eu/regional_policy/en/atlas/programmes?search=1\&keywords=\&periodld=3\&countryCode=ALL \&regionld=ALL\&objectiveld=ALL\&tObjectiveld=ALL (last updated Apr. 6, 2017).

${ }^{82}$ Austria, Belgium, Croatia, Czech Republic, Finland, France, Germany, Ireland, Lithuania, Poland, Slovenia, Sweden, and United Kingdom. Findings based on the analysis of approved ESF, ERDF, and Cohesion Fund Operational Programmes. See Eur. Comm'n, Programmes-Regional Policy, EUROPEAN COMmission, http://ec.europa.eu/regional_policy/en/atlas/programmes?search=1\&keywords=\&periodld=3\&countryCode=ALL \&regionld=ALL\&objectiveld=ALL\&tObjectiveld=ALL (last updated Apr. 6, 2017).

${ }^{83}$ Bulgaria and Italy.

${ }^{84}$ Portugal, Romania, and Spain.

${ }^{85}$ Latvia, Luxembourg, and Slovakia. 
Programs. ${ }^{86}$ At present, spending has not been suspended by the Commission for failure to fulfill the equality conditionalities. ${ }^{87}$

\section{Preliminary Assessment}

\section{The Novelty of Equality Conditionalities}

The analysis of equality conditionalities and their translation into spending action suggests that they add a novel layer to the equality-mainstreaming mandate of Structural Funds. The novelty of conditionality has several dimensions. First, contrary to prior mainstreaming obligations, conditionality is in principle enforced ex ante. The required conduct must be fulfilled before the start of funding operations and only exceptionally after that stage without exceeding the end of the 2016 time frame. Thus, conditionality requirements put substantial pressure on Member States and give important leverage to the Commission as it monitors the fulfillment of the required obligations. Second, conditionality has a sanction attached: The suspension of affected funding. This core difference distinguishes the novel conditionalities from prior mainstreaming action in Structural Funds. In the case of conditionality, failure to fulfill the prescribed criteria may lead to suspension of the affected funds. As highlighted by Andersen, when compared to infringement procedures, the political pressure of a de-commitment of funding may be a more powerful and successful alternative tool for encouraging compliance. ${ }^{88}$ Indeed, the possibility of the EU withdrawing funding has much wider political implications than an infringement fine. Withdrawing funding would directly affect large-scale infrastructure projects, as well as the final beneficiaries of social or rural development or fisheries aid. Yet, as innovative as this response may have been, the following section argues that the approach did not deliver on its promise mainly due to shortcomings in its procedural and substantive construct.

\section{What is the Added Value of the Conditionality Approach to Equality Mainstreaming in Structural Funds?}

While acknowledging the novelty of the conditionality approach and its potential for broader application, in practical terms the legal and operational construct of the conditionalities shows that the novel approach has added little to prior mainstreaming achievements. This Article has shown that the tangled applicability rules, assessment procedures, and fulfilment benchmarks rendered conditionality unnecessarily complex and granted large discretion in its applicability to Member States and the Commission. Looking at its outcome, the tool lacks

\footnotetext{
${ }^{86}$ Croatia, Estonia, Poland, and Slovenia.

87 See Eur. Comm'n, Communication from the Commission: Investing in Jobs and Growth-Maximising the Contribution of European Structural and Investment Funds, COM (2015) 639 final (Dec. 14, 2015).

88 Stine Anderson, The Enforcement of EU LaW: The Role of the European Commission 181-86 (Oxford U. Press 2012 ).
} 
a clear and uniform presence throughout spending programs. Consequently, the administrative capacity to mainstream equality will expectedly vary throughout different thematic areas of funding. If one follows the causal chain "conditionality-capacity building-mainstreaming," uneven implementation of conditionality suggests that mainstreaming itself will ultimately show mixed success depending on the thematic area of funding at stake. In this respect, the funding of fisheries is a particularly telling example; there, equality conditionalities were de facto completely excluded from programming. ${ }^{89}$ In fact, the conditionality practice of the current programming period propagates the findings of previous ex post evaluations ${ }^{90}$ as, once again, all Member States have unanimously declared their formal commitment to equality promotion without a similar practical commitment.

Furthermore, even when conditionality was found applicable, its substantial requirements appear too broad or too narrow to ensure that a sound administrative capacity to mainstream equality is actually achieved. The current vague criteria to be fulfilled are at the same time too broad and too narrow, and leave much space for Member States to maneuver within. The requirements are too broad when asking for training on all EU gender equality, non-discrimination and disability law, and institutional arrangements in each area at all stages of funding implementation. Such training seems too ambitious even for already-trained EU lawyers, not to mention the national officials holding management and control positions for structural funding. At the same time, the conditionality requirements are too narrow as generic training on EU equality law have little to offer considering the complex problem of promoting equality in Structural Funds. In the same vein, it is hard to imagine meaningful engagement of one national equality body operating under the numerous programs implemented by each Member State in the areas of cohesion, agriculture, and fisheries.

Another problematic element refers to the effect of the 2016 extension period, which-in the case of at least four Member States-de facto transformed the ex ante nature of conditionality into an ex post one. ${ }^{91}$ In these cases, one could question the usefulness of fulfilling the pre-conditions ex post factum. As the overall design of operations has already been decided and the responsible authorities designated, ex post training on EU equality law and agreements with national equality bodies may not substantially change the order that was initially agreed on. As far as sanctions are concerned, even if the conditionalities are endowed with a sanction, the sanction is not used for the three equality conditionalities. Thus, the equality conditionalities repeat the experience of prior programming periods,

\footnotetext{
${ }^{89}$ See supra Part C.II.

${ }^{90}$ See supra Part B.II.

${ }^{91}$ See supra note 85 .
} 
leaving significant room for concessions, extended implementation deadlines, and continuous negotiations.

Most importantly, even if all conditionalities are found applicable and diligently fulfilled ex ante or ex post, there is no guarantee that mainstreaming will actually be delivered. The conditionality approach does not require additional mainstreaming obligations. On the contrary, the conditionality criteria are limited to institutional capacity-building action, which would ultimately ensure that existing mainstreaming requirements are properly implemented at the national level. To this end, the conditionalities require Member States to train their staff on EU equality law and establish institutional arrangements with equality bodies. If fulfilled, both criteria are intended to ensure that national authorities have the necessary capacity to deal with equality matters during the implementation of spending. In other words, conditionalities are conceived of as means to enable mainstreaming rather than pure mainstreaming instruments. Therefore, the obligation to mainstream equality remains non-enforceable and the present construction of conditionalities does not change this legal outcome. The only thing that the conditionalities may guarantee is that the administrative capacity to mainstream equality through Structural Funds actually be present before the start of financed operations.

\section{Why Does Mainstreaming Matter and How Should It Be Delivered?}

Based on the findings above, one might ask whether it would ultimately be unfair to conclude that mainstreaming in Structural Funds is incurable. ${ }^{92} \mathrm{Here}$, the emerging baseline question is: To what extent are the EU and national bureaucracies actually capable of promoting equality? Or as Shirin Rai notoriously asked in the context of gender mainstreaming: "Can state institutions promote women's interests?" 93 This is the most vocal critique of mainstreaming. In line with Rai's conclusion, ${ }^{94}$ this Article argues that they could. Moreover, it further argues that, in the specific context of Structural Funds, both EU and Member States should make sure that mainstreaming is thoroughly observed. To support the claim of a pressing need for healthy mainstreaming policy in the area, this Section explains why mainstreaming in Structural Funds matters and also considers several essential pre-requisites on how this goal may be achieved.

\footnotetext{
${ }^{92}$ Analogously, the United Nations have had an equally difficult experience with mainstreaming. See Hilary Charlesworth, Not Waving but Drowning: Gender Mainstreaming and Human Rights in the United Nations, 18 HaRV. HUM. RTS. J. 1 (2005).

${ }^{93}$ Shirin Rai, Institutional Mechanisms for the Advancement of Women: Mainstreaming Gender, Democratizing the State?, in Perspectives on Democratization 15, 18 (2003).

${ }^{94}$ Shirin Ral, PeRSPectives in Democratization 271-74 (Manchester U. Press 2003).
} 


\section{Why Does Mainstreaming Matter?}

First and foremost, a sound mainstreaming culture in Structural Funds is essential to ensure that EU expenditure at the national level meaningfully contributes to the progressive attainment of social justice, while at the same time not further reinforcing pre-existent inequalities, segregation, or discriminatory stereotypes. In this respect, the 2015 own-initiative inquiry by the European Ombudsman on fundamental rights violations in Structural Funds is highly informative. ${ }^{95}$ The European Ombudsman reported numerous instances of discrimination ${ }^{96}$ and cases where EU co-funded programs went against the EU policy on social inclusion and equality. The most visible examples are the institutionalization of children and persons with disabilities. ${ }^{97}$ The investigation also shows that the lack of sound equality mainstreaming in the initial stage of planning led to the formulation of projects that went against the EU spending objective of inclusive growth. ${ }^{98}$ The European Ombudsman drew the Commission's attention to programs that, because of their deficient implementation, substantially limit the effectiveness of planned socially inclusive action. The implementation of programs that targeted the integration of women were often found counterproductive and ill-suited to promote gender equality. ${ }^{99}$ Furthermore, independent reports point to programs whose deficient design did not lead to integration of marginalized groups. ${ }^{100}$ On the contrary, these programs might have strengthened such segregation. ${ }^{101}$

In light of these underlying shortcomings, promoting a sound equality mainstreaming culture remains a crucial-if not the only available-tool to mitigate, at least in part, the risks posed by the current governance of Structural Funds. As identified by Olivier de Schutter, the main advantage of a mainstreaming approach is its anticipatory nature. ${ }^{102}$ In this sense, mainstreaming has more than just the potential to complement

\footnotetext{
${ }^{95}$ European Ombudsman, Decision of the European Ombudsman Closing Her Own-Initiative Inquiry OI/8/2014/AN Concerning the European Commission, EUR. OMBUDSMAN (May 11, 2015), http://www.ombudsman.europa.eu/en/cases/decision.faces/en/59836/html.bookmark.

$96 / d$. at para. 25 .

97 Id. at para. 28.

98 Open SOCIETy Foundation, Main RISKS of Misusing EU Funding IN THE FIELD Of Roma InCLUSION 12 (2015).

99 European Ombudsman, supra note 95, at para. 28(iii). See generally TeRESA ReES, WOMEN AND THE EC TRAINING PROGRAMMES: TINKERING, TAILORING AND TRANSFORMING (1995) (describing the shortcomings of the early EU programs).

100 OPEN SOCIETY FOUNDATION, supra note 98.

$101 / d$.

102 Olivier de Schutter, Mainstreaming Fundamental Rights the Role of the Fundamental Rights Agency, in Monitoring Fundamental Rts. In the EU: The Contribution of the Fundamental RTS. Agency 34 (Philip Aston \& Olivier de Schutter eds., Oxford 2005).
} 
non-discrimination approaches. When properly implemented, mainstreaming is ultimately capable of anticipating and decreasing the necessity of ex post intervention as a remedy for instances of discrimination that occur during the implementation of EU Funds.

Finally, moving beyond the specific context of Structural Funds, equality mainstreaming further derives importance from its explicit EU constitutional mandate. Mainstreaming equality into Structural Funds is not simply an aspirational goal of the Commission. It is an express treaty obligation. Consequently, the current systemic failure to deliver mainstreaming may amount to a breach of EU Treaties. Indeed, in Test-Achats the obligation to mainstream did not require the EU to take immediate action; the Court noted that achieving equality must be done progressively. ${ }^{103}$ Nevertheless, when such action is takenas is the case in Structural Funds-both the EU and its Member States must ensure that "it... contribute[s], in a coherent manner, to the achievement of the intended objective." ${ }^{104}$

\section{The Normative Question-How?}

In their enlightening studies on equality mainstreaming experiences at the national level, Rai and McCrudden identify four essential elements for a successful mainstreaming policy: Clear legal status, demarcation of responsibility, strong accountability, and political will at all levels. ${ }^{105}$

Regarding legal status, McCrudden stresses the necessity of having a definite "hard law" recognition of mainstreaming as opposed to administrative soft law or general principle regulatory solutions, which have been shown to be "inadequate" in the practice of Northern Ireland. ${ }^{106}$ McCrudden further points out that without responsibility, hard law regulated mainstreaming is a "promise [and] not [a] reality." ${ }^{107}$ In this sense, Rai's subsequent assessment of critical elements for responsible "national machineries" is highly helpful. ${ }^{108}$ Rai stresses that the elements most relevant for determining the potential to mainstream equality include: The locations of responsible authorities in the national institutional or administrative hierarchy, the clarity of the mandate, the links between civil society and

\footnotetext{
${ }^{103}$ Test-Achats, supra note 23, at para. 20.

${ }^{104}$ Id. at para. 21.

${ }^{105}$ Christopher McCrudden, Mainstreaming Equality in the Governance of Northern Ireland, 22 FORDHAM INT'L L.J. 1696, 1772-75 (1998). Rai, supra note 93, at 15-39; RAl, supra note 94, at 265-74. 
available human, and financial resources. ${ }^{109}$ The importance of accountability is also stressed, both with regards to executive and legislative powers, ${ }^{110}$ as well as to civil society. ${ }^{111}$ Finally, both scholars stress that mainstreaming would have little to add to equality in the absence of a strong political will. ${ }^{112}$ Only true political engagement at all levels, as opposed to a mere formal commitment, can give effective meaning to mainstreaming. As mainstreaming is itself a best-efforts obligation, rather than being purely driven by results, mainstreaming cannot be completely fulfilled in the absence of good will.

A thorough consideration at the level of the EU and the twenty-eight national legal and administrative systems of all the above-analyzed factors is indeed a heavy enterprise. Currently, from all the enumerated factors, in the context of Structural Funds, we may only be able to successfully identify one-the will. The legal status of mainstreaming remains vague, at the borderline between a general principle and a discretionary obligation that has no clear benchmarks indicating how it is to be achieved. Moreover, EU legislators have given Members States large discretion while at the same time leaving the Commission without credible enforcement tools to ensure compliance with mainstreaming commitments. As a result, mainstreaming is seen as an accessory rather than a mainstream obligation in EU spending. From the point of view of responsibility, the delivery of the policy rests in the twilight area between the Commission and Member States which is further diluted throughout at least twenty-eight national administrations. To put it in Manzey's metaphor, the policy is "everybody's responsibility-and nobody's-responsibility." 113

Finally, accountability is weak. Neither the Commission nor the Member States are legally bound to or politically accountable for failures of mainstreaming. The Commission's reports on the implementation of Structural Funds submitted to the European Parliament do not explicitly report on mainstreaming. Similarly, the national reports on the implementation of funds submitted to the Commission do not indicate if and how mainstreaming was pursued through spending. Moreover, the Commission has never considered infringement proceedings for failure to mainstream equality and, in the current programming period, has never considered suspending payments for failure to fulfill the equality conditionalities. And, most concerning, the present incoherent and hesitant approach to equality mainstreaming has ultimately led to generalized mainstreaming fatigue and a weakening of the policy's initial noble goal. Nevertheless, there is political will. And, where there is a will, there is a

\footnotetext{
${ }^{109} / d$.

${ }^{110}$ McCrudden, supra note 105, at 1173.

${ }^{111}$ RAl, supra note 94 , at $266-67$.

112 Id. at 272; McCrudden, supra note 105, at 1173.

113 Sonia Mazey, Gender Mainstreaming Strategies in the E.U.: Delivering on an Agenda?, in 10 FEMINIST LEGAL STUDIES227, 228 (2002).
} 
way. But, for now, the equality-mainstreaming mandate of the Structural Funds must wait for a new opportunity. The negotiation and adoption of the next multi-annual financial regulations may be a right one. It remains to be seen whether this next opportunity will be explored in practice.

\section{E. Conclusion}

Equality conditionality is a very new and highly interesting tool of EU spending. It was conceived as a remedy for the equality mainstreaming deficit of Structural Funds. The aim was to secure sound administrative capacity to promote the highest possible dimension of equality via EU spending action. While acknowledging the novelty of the conditionality approach, the tool's practical design and operation suggest that it will not substantially improve the modest achievements of prior programming periods. From this point of view, the tool's novelty in design does not match its novelty in operation.

Despite the modest reach of the novel conditionality arrangements and the limited overall success of mainstreaming in Structural Funds, this Article argued that a sound mainstreaming policy in EU spending is not only desirable, but also fundamental. The lack of an effective culture of equality during funding design and implementation often leads to outcomes where EU funds have a limited effect on dismantling inequalities. Even worse, sometimes the outcomes go against the goal of the progressive achievement of equality. Furthermore, as mainstreaming is an express legal obligation firmly embedded in the EU Treaties and funding regulations, the limited success of equality mainstreaming in Structural Funds may amount to a breach of EU law.

Making mainstreaming work in Structural Funds is the responsibility of both the EU and its Member States, which have committed themselves to mainstream equality in spending and must therefore fulfill the undertaken obligation. To fulfill the obligation, the current mainstreaming policy of Structural Funds needs a new cure. This cure should be based on solid legal recognition, clear responsibility, increased accountability, and pervasive political engagement at all levels. If the administration of the cure is further delayed, there is a serious risk that equality mainstreaming will be rendered de facto incurable. 
